\title{
The green soul of the concrete jungle: the urban century, the urban psychological penalty, and the role of nature
}

\author{
Robert lan McDonald ${ }^{1 *}$ (D) Timothy Beatley ${ }^{2}$ and Thomas Elmqvist ${ }^{3}$
}

\begin{abstract}
By 2050, there are forecast to be 2.4 billion more people in cities, and this century could rightly be called the urban century. This paper argues that, paradoxically, without the use of nature the urban century will fail. We review three literatures to assess the scientific support for this proposition. First, studies from economics show that it is the extreme potential for interaction that makes cities centers of productivity, innovation, and creativity. Second, many health studies document the increase in stress and greater prevalence of some mental disorders in cities, and we argue that it is the constant interaction of urban life that leads to this urban psychological penalty. Here we show that $46 \%$ of humans are living at population densities where global datasets suggest that this psychological penalty may be an issue, a fraction that will only grow as urbanization continues. Third, ecosystem service research shows that even a brief interaction with nature has mental health benefits, alleviating symptoms of this psychological penalty. Global datasets suggest that currently, only $13 \%$ of urban dwellers may be living in close enough proximity to nature to experience its mental health benefits. We argue that natural features in cities will be an essential part of the urban century, a way to have all the benefits of our urban, connected world yet also have that urban home be a place where we can psychologically flourish. We discuss two specific ways governments are trying to integrate nature into citizens' lives, through Green Prescriptions and the Biophilic Cities Network.
\end{abstract}

Keywords: Agglomeration benefits, Biophilic cities, Nature dose-response, Parks, Psychosis, Stress, Urban population growth

\section{The urban century}

We are living in the urban century. Humanity is in the midst of the greatest migration in our history in absolute terms, the movement of people from rural areas into urban ones. More than 2.4 billion additional residents are expected in the world's cities and towns by 2050, as migrants join those newly born in cities [1]. One study forecasted that a new area of 1.2 million $\mathrm{km}^{2}$ by 2030 , the size of the country of South Africa, will be developed for urban use [2]. We are designing now the cities and neighborhoods of the future, on an epic scale (Fig. 1). By one estimate, more homes will be built in the next two decades than have been built over several centuries in Europe [3].

\footnotetext{
* Correspondence: Rob_mcdonald@tnc.org

${ }^{1}$ Global Cities Program, The Nature Conservancy, 4245 Fairfax Drive,

Arlington, VA 22203, USA

Full list of author information is available at the end of the article
}

This unprecedented urbanization is affecting many aspect of human society and profoundly shaping our global civilization. Urbanization has brought with it economic growth and vitality for some sectors and groups, while others feel left behind [4]. Urban growth has been associated with political change and sometimes instability, as a new social order arises in cities [5]. And of course our urban lifestyle has had and will have deep implications for the environment [6]. Urban growth will directly affect natural habitat through land expansion, while the urban form and consumption patterns will affect greenhouse gas emissions, natural resource use, and water security. Cities also depend on a healthy environment for proper functioning in many ways. Throughout this review paper, our focus is on the ecosystem services urban natural features provide for human health, rather than examining the many ways urban

(c) The Author(s). 2018 Open Access This article is distributed under the terms of the Creative Commons Attribution 4.0 International License (http://creativecommons.org/licenses/by/4.0/), which permits unrestricted use, distribution, and 


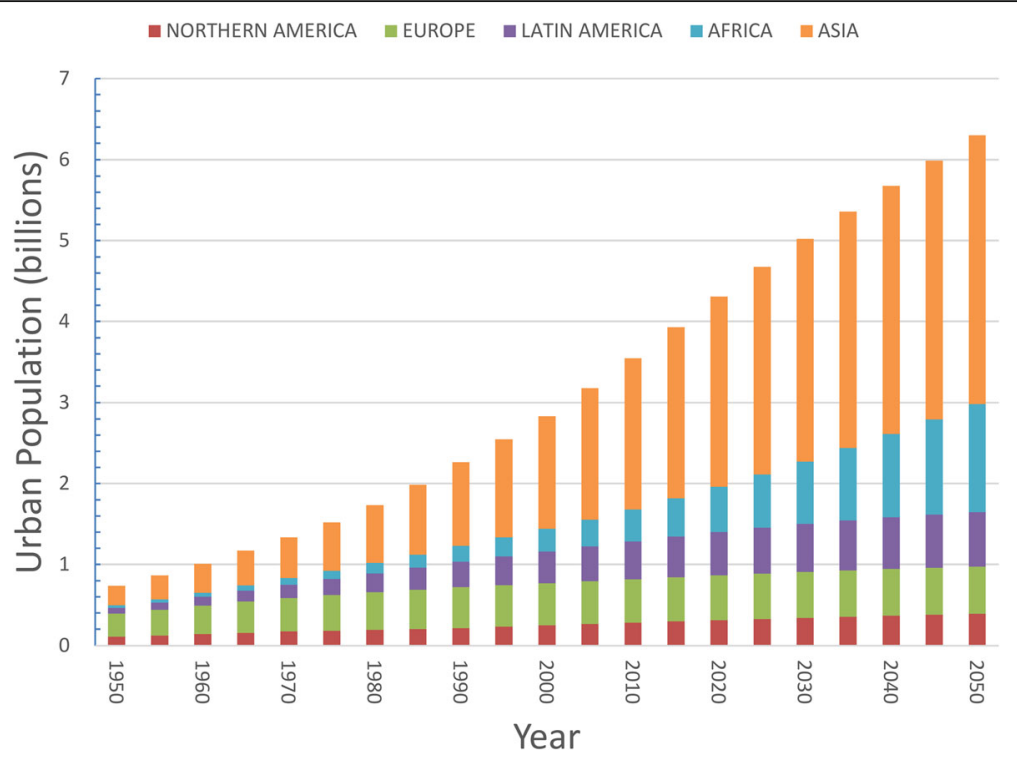

Fig. 1 Urban growth over time. Total urban population, by region, as estimated and forecast by the UNPD World Urbanization Prospect dataset (2014). Note that the Latin America region includes the Caribbean. Note also that Oceania, including Australia and New Zealand have relatively few urban dwellers (42 million) and are not shown on this figure

growth will affect biodiversity and ecosystem function per se [6-9].

In Quito in 2016, representatives of the world's governments at the UN Habitat III Conference agreed to the New Urban Agenda [10]. The document continues the focus of past UN Habitat agenda on the provision of adequate housing for all, and especially on upgrading the housing of the close to 1 billion people living in informal settlements or "slums". But recognizing the broad links between urbanization and other aspects of human society, the New Urban Agenda also discusses many other issues, such as equity, sustainable economic development, gender, and affordable housing. This includes the environment, where the document focuses on commitments to minimize the impact of cities on the natural world while also ensuring a safe and clean environment for those in cities. There is also discussion of the role of properly designed cities in ensuring urban stability and resilience. Most importantly for the goals of this paper, there is one mention of ecosystem and environmental services as a potential tool to reach resilience.

This review paper assesses the scientific evidence for the proposition that natural features in cities like parks, remnant natural habitat, and street trees can play a broader role than merely reducing risk and increasing resilience, that they are essential to solving one of the central paradoxes of the urban century: cities are quintessentially human, yet often shockingly inhumane. Our review focuses on three literatures. First, we review the literature on the positive economic and social benefits of cities, focusing on the way cities promote interaction, in multiple senses. Second, we review the literature on urban life and health, focusing especially on the relationship between urban life and mental health. Third, we review research that looks at the effect of interaction with urban nature on mental health. Finally, we end by discussing two examples of how governments are trying to integrate nature into their citizens' lives, Green Prescription programs and the Biophilic Cities Network.

\section{Cities as quintessentially human}

Why is so much urban growth happening? Demographers sometimes identify push factors driving people from rural areas, such as the collapse of rural economies or political instability. Also important are pull factors, as the positive benefits of being in a city draw people to migrate to the city [11]. Regardless of whether push or pull factors dominate, a growing fraction of people live in cities because they are a useful way of structuring society, what one writer has called "our greatest invention" [4]. The core ingredient of cities' success seems to be how cities enable greater proximity of people and firms [12]. Proximity promotes interaction and speeds the pace of life, leading to individual and social benefits [13-15].

Aristotle famously referred to humans as a social animal [16], by which he meant that our unique skill and love for interacting with one another is part of our species essence. In cities, one could argue we are creating the perfect space for social interaction. If man is a social animal, then cities with their density and proximity are our ideal habitat. Cities could therefore be seen as quintessentially human, an expression of our deep need for social interaction. 


\section{Urban benefits to production}

There is a voluminous literature on the benefits of proximity to individuals and firms, which is sometimes called agglomeration economics [12, 17]. A large fraction of the urban economics literature focuses on the benefits of agglomeration to production. There are many ways to classify these benefits, but one useful classification focuses on the benefits of Sharing, Matching, and Learning $[18,19]$.

Proximity enables sharing of infrastructure and resources. Transportation infrastructure, such as roadways or train lines, makes more economic sense when multiple people can use the infrastructure. For trade, facilities like seaport or airports are essential, and their high cost of construction is only economical when multiple entities can help pay for and use them [20]. Sharing benefits can also occur within a firm, particularly one that exhibits increasing return to scale in production. A firm that finds it can produce goods more efficiently by sharing expensive machinery among different production processes may find that concentration of production in one or a few locations is preferable to dispersed operations [19].

Second, the proximity of people and firms facilitate matching $[19,21,22]$. Having multiple firms in the same sector located in one area leads to a pool of workers qualified to work in that sector. This thick labor market makes it easier for firms to find qualified people for specialized jobs. Matching can also occur between firms. For instance, when one firm's output good is another firm's input good, proximity can aid in matching up firms, reducing the transaction costs of commerce.

Third, the proximity of people and increased potential for face-to-face interaction promotes learning [23-25]. Despite the rise of technologies that allow communication at a distance, such as the telephone and the Internet, research shows that some kinds of "sticky" knowledge is best transmitted through direct interactions [26]. Much of the research into this topic has focused on the development and history of certain innovation clusters, such as the rise of the computing industry in Silicon Valley, where personal interactions among high-tech workings has been shown to be key to knowledge generation [27]. Empirical evidence that look at rates of patent generation and other metrics of innovation show that larger cities generally have higher rates of innovation [13], consistent with the idea that increased interaction leads to more learning.

\section{Urban benefits to consumption}

Historically, the focus of urban economics was on the benefits of agglomeration to production. However, in recent decades an increased research focus has been on cities as centers of consumption [28,29]. Living in a city brings with it access to many amenities and services that are not as frequently available in rural areas: restaurants serving all variety of food, good museums and theaters, etc. Indeed, parks and street trees can be viewed as a type of amenity, part of the overall attractiveness of cities [30], although later in this paper we argue that the evidence suggests such natural features have a greater role to play than as a mere amenity.

Some economists have taken these arguments further, arguing that consumption benefits are now a key reason for urbanization. A famous paper by Glaeser and colleagues called Consumption City [28] noted that rents in cities have grown faster than wages, suggesting workers interest in living in cities has grown faster than firms'. Reverse commuting has grown as a phenomenon, with people choosing to live in the city center for the cultural life and consumption possibilities it offers, even if it is farther from their job and has higher rent than a more suburban location. While urban life has its stresses and difficulties, it is worth remembering that a sizable fraction of people prefers living in cities over the alternative lifestyle in rural areas.

\section{An urban world, ready or not}

These various benefits of cities occur because of proximity and the increased interaction it entails. These economic benefits from urbanization are often unequally distributed within cities, and it is important to note that not all sectors of society necessarily benefit from urbanization. However, the historical record suggests that overall these economic benefits of urban form are strong enough that they drive most societies toward urbanization. Over the last century, almost every country has urbanized as it has economically developed (Fig. 2). Research suggests that the causality here goes both ways: urbanization brings economic benefits and hence higher growth in GDP, while economic growth also appears to encourage urbanization [20].

Some countries have tried to slow or limit urbanization, out of fear of the pace or magnitude of changes it might bring. These policies are often seen as failures, in the sense that urbanization occurred anyway (cf., [31]). The demographic and economic forecasts are clear [1]. Urbanization is coming, and we argue that it is smarter for policymakers to plan for the coming urban century than to fight to stop its arrival. Indeed, the urban century will bring with it tremendous economic benefits.

\section{The urban health penalty}

We argued above that cities are quintessentially human, that their form reflects a deep-seated desire for social interaction. But cities are also shockingly inhumane. The concentration of people leads to a concentration of environmental problems, as (among other things) local resource use and waste generation degrade local environmental 


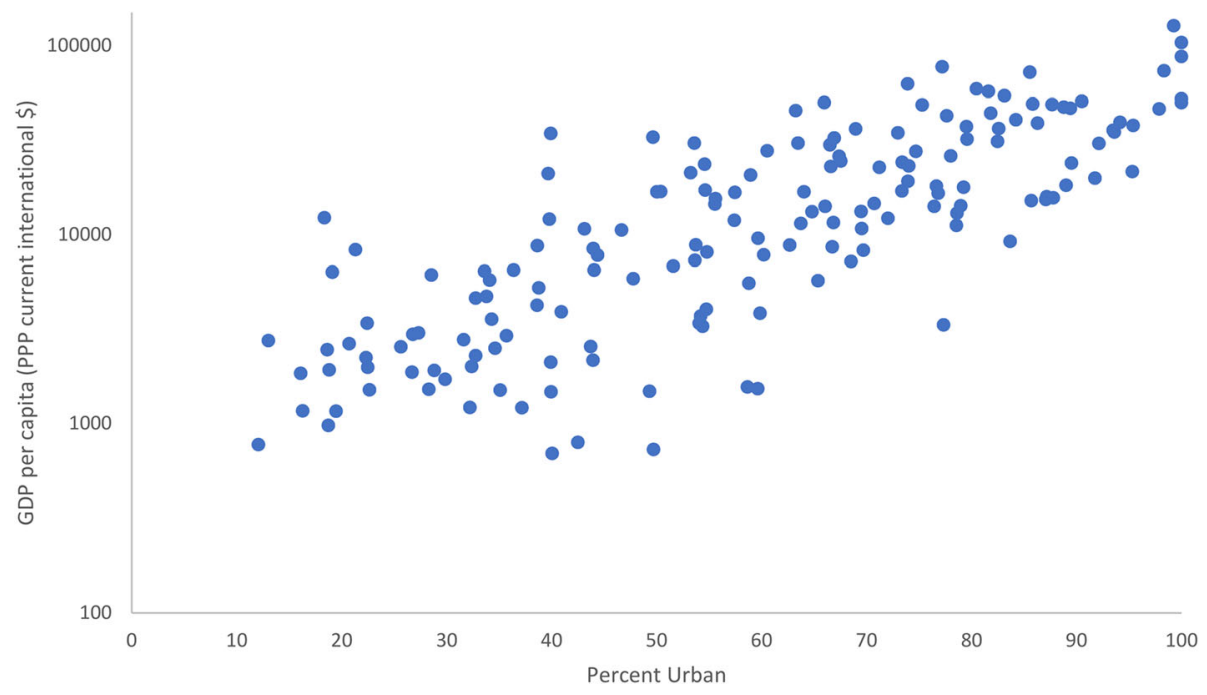

Fig. 2 Urbanization and economic development. The relationship between the percent urban of a country's population and its GDP per capita. Urbanization data taken from the UNPD for 2015. Per-capita GDP taken from the World Bank. Some small island states and nations are excluded from this graph, as are nations with missing data

conditions [32]. Cities create a local environment with far different environmental conditions than the ones we evolved as a species to handle [30]. Thus, in this sense, the urban environment is inhumane, by not being in accord with our organism's design and capacities.

\section{The urban health penalty historically}

Much of urban history can be seen as a struggle to make cities more humane. This is particularly true for health, a focus of many of the largest urban innovations over the last several centuries [33]. Historically, urban dwellers had shorter lifespans than rural dwellers, a phenomenon called the urban health penalty. The term "urban penalty" originated in the study of nineteenth century English demography [34], where urban mortality rates, particularly from communicable diseases like tuberculosis, was substantially higher than in rural areas. Infant mortality rates were also higher in urban areas up until the late nineteenth century. Studies in the United States found a similar pattern, focusing in on the environmental determinants of the "urban health penalty" [35].

One useful framework for thinking about how cities have dealt with environmental challenges to health is the Urban Environmental Transition (UET). Formulated by McGranahan and colleagues [33, 36], the UET argues that often cities have dealt with environmental challenges in a predictable temporal order (Fig. 3). First, cities focused on acute, local (neighborhood-scale) challenges, especially providing clean drinking water and sanitation to remove human waste. Then, cities moved to less acute, more city-level issues, such as air quality. Finally, cities moved to thinking about regional or global problems, such as acid rain or climate change. At each stage, cities often can solve a health challenge while displacing the environmental burden elsewhere outside the city center, following the famous maxim that "the solution to pollution is dilution." Recent papers have suggested that cities in the developing world are not sequentially moving through these stages, but are tackling multiple transitions at once [37]. Regardless, while the UET may not be a guide to the sequence in which future cities will act, we think the UET is a useful framework for understanding

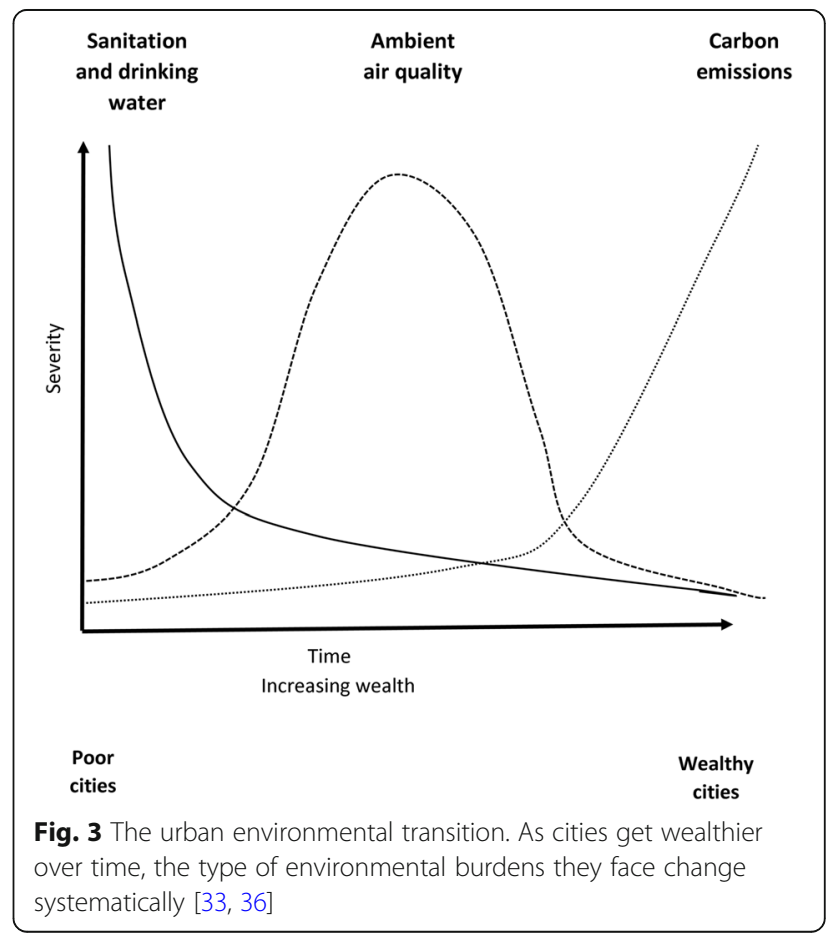


how historically many cities have experienced and dealt with environmental issues.

Dealing with sanitation and water quality is one of the first steps in the UET. For instance, London and other cities in England began to tackle this problem in the nineteenth century. These sanitation improvements, coupled with improvements in the nutrition and diet of the urban poor, led to an improvement in human health. Since then, water supply systems and sanitation systems have dramatically decreased mortality rates, particularly infant mortality. This transition to the "Sanitary City" [38] was the first and arguably most important step taken by cities in removing the urban health penalty. Obviously, however, much work remains to be done, as an estimated $15 \%$ of urban dwellers globally lack safely managed drinking water sources and $16 \%$ of urban dwellers lack access to at least basic sanitation [39]. While these figures are substantially better than for rural areas, that still means that hundreds of millions of urban dwellers lack safely managed drinking water sources and basic sanitation, especially concentrated in informal urban settlements in developing countries.

In developed countries, efforts to address problems from ambient air pollution began later. In London, for instance, the infamous Great London Smog was still severe enough in 1952 to kill close to 12,000 people in 1 week [40]. In the decades since, however, air pollution emission controls have dramatically cleaned up many urban airsheds. London's concentrations of suspended particulate matter are now less than a fifth of what they were in the 1950s [41]. In the United States, for instance, particulate emissions $\left(\mathrm{PM}_{10}\right)$ fell by $57 \%$ between 1980 and 2016 [42]. As with the situation with water, much work remains to be done of course. Ambient particulate matter pollution still kills more than 3 million people per year, in both rural and urban areas [43].

\section{The urban health penalty today: Obesity and mental health}

The urban health penalty has now in aggregate disappeared, as mortality rates are now lower for urban dwellers than rural dwellers [44]. This is particularly noticeable for the infant mortality rate: in developing countries the Demographic and Health Surveys (DHS) show an average of 86 deaths (per 1000 live births) for rural areas, 75 for the urban poor, and 56 for the urban non-poor [45]. That is, even the more than 800 million people who live in informal or "slum" settlements [46] are generally healthier than their rural counterparts. However, two major facets of the urban health penalty remain.

First, one aspect of physical health continues to be worse in cities: obesity and its associated diseases [47]. Worldwide, obesity has more than doubled since 1980, now affecting more than 600 million people [48]. Obesity is most prevalent when there is increased intake of calorie-rich foods and less physical activity [49]. Both conditions are more common in cities, as greater incomes allow more calorie intake and a larger proportion of jobs are sedentary than in rural settings. It is unclear whether it is cities per se however that are responsible for obesity. In the United States, for instance, where automobiles are available to most households, the global average trend is reversed, and rural dwellers are generally more obese than urban dwellers. Indeed, there is evidence that dense urban living in the U.S. is associated with more physical exercise and lower body mass index (BMI) [50].

Second, some aspects of mental health appear to be persistently worse in urban areas than in rural ones, leading to an urban psychological penalty [51]. Urban life has been associated with higher levels of stress than rural areas, as well as with changes in brain function [52]. Sundquist et al. [53] studied more than 4 million adults in Sweden, finding a significant increase in the incidence of psychosis and depression among populations living at higher densities in cities than those living in more rural areas. Similar large-population studies have been done in Denmark [54, 55] and the United Kingdom $[56,57]$, with each study defining urbanicity slightly differently and measuring different components of mental health. The effect appears to occur in developing countries as well. A Chinese study of rural to urban migrants found a positive association with schizophrenia [58], and a study in Sao Paulo, Brazil, found higher self-reported problems of mental illness in higher density neighborhoods [59]. Interestingly, the effect of urban life on mental health seems to vary depending on age. In children, some studies have reported that urban life appears to be associated with greater frequency of Attention Deficit Hyperactivity Disorder (ADHD) [60], although other studies have found no association [61]. In adults, urban life appears to be associated with schizophrenia [62, 63], as well as greater incidence of psychosis [53].

These studies suggest that the dose-response relationship between urbanicity and the urban psychological penalty is complex, varying by disease and by the urban cultural context [55]. However, there is a clear empirical trend for the higher population densities found in cities to be associated with a greater incidence of mental health problems. In Fig. 4, we assemble information on the fraction of humanity living at different population densities, using the approximate classes used in the Sundquist et al. [53] paper. In 2000, 2.5 billion people lived at densities greater than 800 people per square kilometers $(41 \%)$, a figure projected to grow to 3.7 billion people $(46 \%)$ by 2020 . Note that these are the same population density categories for which the Sundquist 


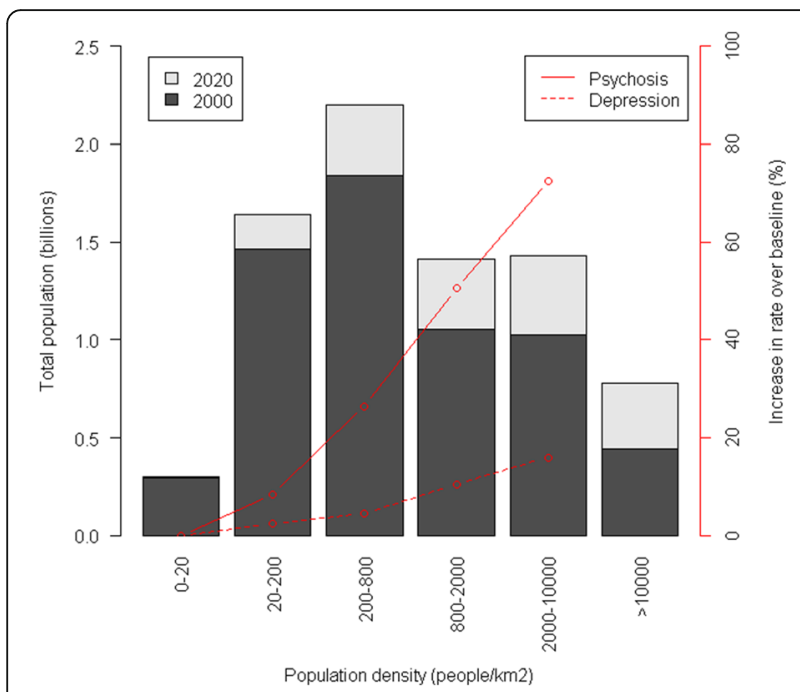

Fig. 4 Population density and the urban psychological penalty. The bar chart shows the total global population living in different population density classes, calculated from the Gridded Population of the World for 2000 and 2020. The red lines show the increase in the hazard rate over baseline for two common mental illnesses, taken from Sundquist et al. [53], who studied 4.4 million people aged 25-64 in Sweden. Shown is the average increase in hazard rates across men and women. Note that Sweden does not have many neighborhoods with population densities above 10,000 people $/ \mathrm{km}^{2}$, so the Sundquist et al. results are not directly applicable to the top population density category

et al. [53] paper showed an increased incidence of depression and psychosis. If this is applied globally, it would imply that close to half of humanity is living at urban densities that significantly increase the risk of mental health problems.

\section{Causes of the urban psychological penalty}

The urban psychological penalty has been explained through three categories of causes [cf., 35]. First, cities have a different mix of populations than rural areas. This structural issue makes analyses comparing urban and rural dwellers challenging. Those of lower economic status are sometimes concentrated in certain cities or neighborhoods. So sometimes are marginalized racial or ethnic groups. Since these populations are sometimes more prone to mental health problems, their concentration in cities make urban areas statistically correlated with poor mental health.

Second, in certain cities or neighborhoods urban life (urbanicity) may lead to a breakdown in social cohesion, the willingness of members of a society to cooperate with each other in order to survive and prosper [64]. There is debate in the literature $[65,66]$ about whether this breakdown in social cohesion is due to urbanicity per se, or whether it simply is statistically more likely to occur in cities. Cities tend to have more single parents, as well as more families with no extended family living nearby. Cities are also commonly a place with more transient or temporary residents, which can also lead to less social cohesion. Since social cohesion is linked to mental health, processes in cities that reduce social cohesion are associated with poorer mental health.

Third, cities have numerous environmental stressors that are associated with poor mental health [67]. The greater ambient noise in urban environments is associated with higher stress levels and mental health issues $[68,69]$, as is the greater visual stimulation and "light pollution" in cities [70]. It appears that living at higher densities (crowding) is associated with poor mental health, at least when the crowding is with non-family members [71, 72]. However, this crowding is part of what makes cities humanity's "greatest invention"higher densities and a faster pace of life are part of what makes cities successful economically [4]. It is ironic that the same phenomenon, cities' capacity to increase interaction, is what makes cities great and what makes cities mentally inhumane. This "urban psychological penalty" may not be as easily engineered away with grey infrastructure, as were other facets of the urban health penalty (e.g., water-borne diseases).

\section{Nature as a potential solution}

The urban ecosystem service and urban social-ecological approach has recently developed into several programs exploring the scope and potential of "Nature-based solutions" [73]. Nature-based solutions are actions which are inspired by, supported by or copied from nature and aim to address a variety of societal challenges in sustainable ways, while also contributing to green growth [74]. Nature based solutions for sustainable urbanization rely in large part on natural areas and features ("natural infrastructure") in and around cities to generate essential ecosystem services [30, 75].

There are many different ecosystem services that are important to human well-being. A short list of ecosystem services most relevant to cities is shown in Table 1. Much of the discussion around nature-based solutions has focused on regulating services that can reduce various risks to urban residents. For instance, natural habitats and wetland features can reduce coastal [76] and riparian flood risk [77, 78], as well as help manage stormwater [79]. Conservation actions upstream in a city's source watershed can maintain raw water quality and improve a city's water security [80]. Street trees and parks within the urban fabric can reduce air temperatures, thus reducing the urban heat island effect [81]. Trees also can improve air quality, by reducing concentrations of particulate matter and other pollutants [81]. Many of these different ecosystem services generated in 
Table 1 Ecosystem services of greatest relevance to cities, classified according to the scheme of the Millennium Ecosystem Assessment [75, 115]. Adapted from McDonald [30]

Ecosystem service
Provisioning services:
Agriculture (crops, livestock, aquaculture, etc.)
Water (quantity)
Cultural services:
Aesthetic Benefits
Recreation \& Tourism
Physical Health
Mental Health
Spiritual value and sense of place
Biodiversity
Regulating services:
Drinking water protection (water quality)
Stormwater mitigation
Mitigating flood risk
Coastal protection
Air purification (particulates, ozone)
Shade and heat wave mitigation

the urban landscape may have impacts on health, either directly or indirectly [82].

However, in this section we focus on a small subset of ecosystem services that directly affect health, and can help counteract the "urban psychological penalty". Urban nature's relationship to health has been shown to be complex, operating through numerous pathways [83, 84], with some significant research gaps remaining in current scientific understanding [85]. Note that most studies studying the relationship between nature and health use observational rather than experimental data, controlling for other potentially confounding variables through statistical methods. In our review we use the term "association" or "correlation" when describing the results of studies using observational data.

\section{Physical health}

One major pathway by which parks and other natural features affect health is by encouraging recreation and physical activity. For instance, Wolch et al. [86] tracked the health of more than 3000 children in Los Angeles across two decades, and found that children living with a park within $500 \mathrm{~m}$ of their homes had lower Body Mass Index (BMI) and better health outcomes. Ewing et al. [50] reviewed all United States counties and related an index of sprawl with reported walking data and measures of BMI, finding that counties with a more sprawl urban form had less walking and higher BMI. The reasons for this correlation are a little unclear. Hartig and colleagues [83] described three activity domains: our lifestyle while at work, which seems likely to be little influenced by urban form; transport, where the availability of bike lines and walkable streets can encourage physical activity while commuting; and leisure activities, where park availability may significantly increase physical activity during recreation.

Physical activity improves physical health by reducing obesity, but also has mental health benefits, making it hard to separate the effect of recreation on physical health from the effect on mental health. Regardless, aggregate health benefits appear significant. In England, the benefits of urban greenspaces for physical and mental health have been estimated to reduce treatment costs by $£ 2.1$ billion [82].

\section{Mental health}

Spending time in the natural environment or interacting with natural features (street trees, parks, and gardens) is not only of importance for physical recreation, but has benefits to mental health. Here too there is a large literature documenting the multiple pathways by which interaction with nature can affect mental health [87, 88].

\section{Increased social cohesion}

There is some evidence that social cohesion,, the willingness of members of a society to cooperate with each other in order to survive and prosper [64], may be increased or at least facilitated by having greenspace. For instance, Maas and colleagues [89] reported that access to urban parks and green space contributed to a sense of place and social cohesion and interaction. De Vries and colleagues [90] showed a correlation between street-level greenery and perceived social cohesion in the neighborhood. Perhaps one of the most well-known papers on this topic took place in Chicago [91], where public housing residents who were randomly assigned to apartments with nearby nature had greater social contact than those residents without nearby nature.

\section{Stress reduction}

There is now a large set of studies that show that time in nature or residential proximity to nature can reduce stress, whether measured through self-reporting (e.g., [92]) or from levels of cortisol (e.g., [93]). This effect has also been shown in workplaces, with greater indoor contact with nature correlated with less job stress, fewer subjective health complaints, and fewer sick days [94]. There are two main theories of how this stress reduction occurs, which are not mutually exclusive. Stress Reduction Theory [95] argues that time in natural areas is correlated with reduced exposure to environmental stresses like noise and light pollution. This reduced exposure to 
stressors, as well as time in a natural environment that we have evolved to find relaxing, allows people to reduce their stress. Attention Restoration Theory [96] argues that urban life is taxing because there are so many stimuli that require attention, and that time in nature replenishes our ability to pay attention and focus, thus leading secondarily to a reduction in stress.

\section{Improvement in mental health}

Proximity to nature or exposure to nature has also been shown to be correlated to a reduction in some mental health disorders. One systematic review [88] found 21 articles that focused on perceived mental health, with some of the most compelling studies using a longitudinal design. For instance, using data from the British Household Panel Survey, Alcock and colleagues [97] showed that those who moved from a neighborhood with less greenery to one with more greenery showed an increase in mental health. A related study using the General Health Questionnaire found a similar effect [98]. A study of data on more than 260,000 Australians [99] found that those with greater percentage green space within $1 \mathrm{~km}$ had lower rates of psychological distress as well as higher rates of physical activity, suggesting that recreation in greenspace may be a causal mechanism improving mental health.

\section{Do we have enough nature in our cities?}

Given this growing literature documenting the physical and mental health benefits of exposure to nature, several studies have begun to try to measure the dose-response curve, understanding how much exposure to nature is needed to receive benefits to health. For instance, Lovasi and colleagues [100] found that a 1-SD increase in tree density (an increase of 343 trees $/ \mathrm{km}^{2}$ ) near homes was associated with a $29 \%$ reduction in the prevalence of asthma. A study in Brisbane City, Australia found that visits to outdoor greenspaces of $30 \mathrm{~min}$ or more per week resulted in a 7\% reduction in depression and 9\% reduction in high-blood pressure [101]. Most recently, Cox and colleagues [102] studied individuals in southern England, testing how neighborhood tree cover within $250 \mathrm{~m}$ of a house correlated with the prevalence of several mental health diseases. Dose-response modelling showed a threshold response, with $50 \%$ less depression and $43 \%$ less stress in neighborhood with more than $20 \%$ forest cover and $56 \%$ less anxiety in neighborhoods with more than $30 \%$ forest cover.

Extrapolation of the results of these studies to other sites must be considered exploratory and preliminary, since other literature indicates the magnitude of the impact of nature on physical and mental health likely varies by sociocultural context and depends on complex interactions between urban form, human society, and natural features [83]. Nevertheless, given that humanity is in the midst of the fastest period of urban growth in our species history, it seems worthwhile to ask: what fraction of the world's urbanites get enough nature now?

To address this question, we took data on neighborhood forest cover for 245 major cities globally [81], and classified $1 \mathrm{~km}^{2}$ neighborhoods into the same forest cover categories used by Cox and colleagues [102]. This analysis therefore looked at the variation both within cities and among cities. A full analysis of the climatic, socioeconomic, political, and historical reasons for variation in forest cover is beyond the scope of this paper, but other researchers have noted that neighborhoods of lower socioeconomic status, or cities with fewer economic resources, often have less lower forest cover [103, 104].

Currently, only $13 \%$ of urban dwellers are living in neighborhoods with more than $20 \%$ forest cover (Fig. 5), the threshold found by Cox and colleagues to be needed to receive a protective effect against depression, stress, and anxiety. Our results suggest that most urban dwellers are living in environments with low levels of nature exposure and may thus be at greater risk of the urban psychological penalty. Our new urban world, while representing something quintessentially human,

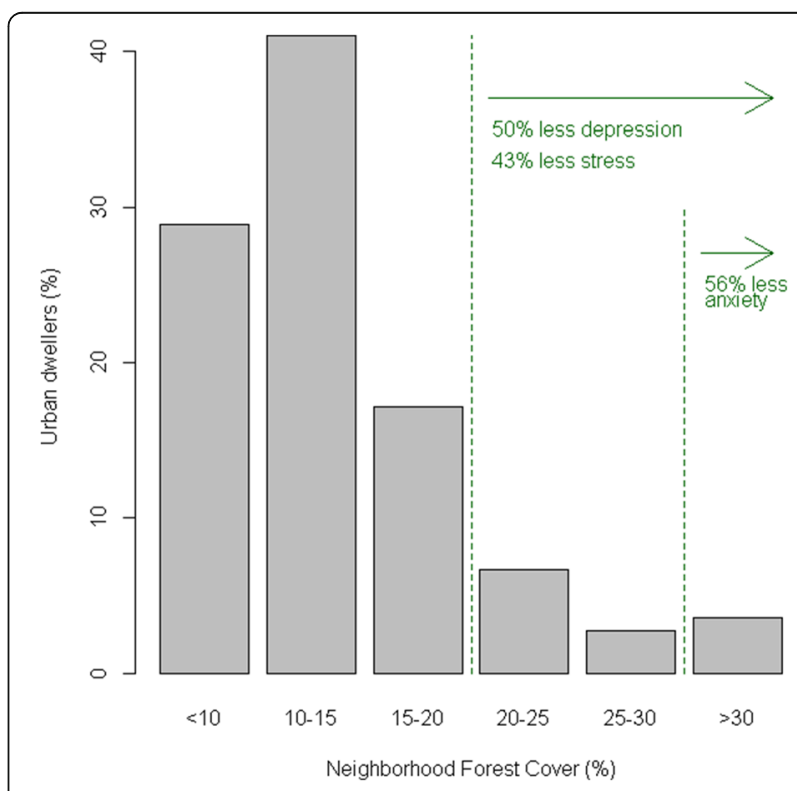

Fig. 5 Forest cover in urban neighborhoods and its impact on mental health. The bar chart shows the fraction of urban dwellers who live in neighborhoods with varying levels of forest cover. Forest cover was estimated for 1-km square neighborhoods in 245 major cities globally, as part of the Planting Healthy Air report [81]. The green lines shows thresholds in vegetative cover and its relationship to mental health, as identified by Cox et al. [102], who surveyed 263 respondents in three towns in the United Kingdom. They found that the odds-ratio of depression, stress, or anxiety being reported was significantly higher when houses had less than these thresholds of vegetative cover in the $250 \mathrm{~m}$ around their home 
also is shockingly unnatural, likely negatively affecting mental health.

\section{Biophilic cities}

Increasingly urban planners and policymakers recognize the potential of designing cities in ways that integrate nature. Some planners have begun to speak of biophilic cities or biophilic design $[105,106]$. The premise of the idea of biophilia [107] is that as a species we have an innate connection to nature, that we are happier, healthier and able to lead more meaningful lives when nature is around us where we live and work. Biophilic designers argue that the integration of nature into urban design and planning is an important step toward future cities that are uplifting, restorative, beautiful and designed around a sense of connection with and wonder about the natural world. A full presentation of the theory of biophilic design is beyond the scope of this work. Below, we highlight two ways that biophilic cities, in which nature is integrated into its citizens' everyday lives, can have tangible benefits for mental and physical health. While our examples are primarily from cities in the developed world, where these two types of programs are most common, we believe that they can potentially be applied in cities in the developing world as well.

\section{A nature prescription}

Numerous programs in cities are trying to increase opportunities for urbanites to interact with nature, ensuring that residents receive an adequate dose of nature into their everyday life. From "nature bathing" programs in Korea to nature kindergartens in Scandinavia, these diverse program each bring a different philosophy and structure to the common task of connecting people with nature for mental and physical health benefits.

Some of the best evidence that such programs to increase nature interaction can have health benefits comes from New Zealand, where the Ministry of Health runs a Green Prescription (GRx) program. For every ten Green Prescriptions written, subjects achieved 150 min of moderate or vigorous outdoor activity, which was associated with a $20-30 \%$ reduction in all-cause mortality [108]. Long-term follow-up surveys shows that this effect persists over time, for at least 2-3 years [109]. Overall, the program has been shown to be a cost-effective way to improve public health [110].

It is worth noting that the New Zealand GRx program, like many others that implement nature prescriptions, has multiple pathways by which participants' health may benefit. Physical activity goes hand in hand with time outside, interacting with natural features while also taking a break from stressful activities.
Biophilic urban design and the Biophilic cities network If exposure to nature is key to combating the urban psychological penalty, that suggests that we cannot just get our necessary dose of nature on an occasional trip to a remote national park; rather, nature has to be experienced daily, and has to be integrated into our homes, neighborhoods, and work spaces, where we spend the bulk of time.

Biophilic design principles and strategies are necessary at the building scale (and in interior spaces, given the amount of time we spend indoors), as well as at the scale of the neighborhood, city, and region. Natural elements and spaces must be integrated and connected across these scales. Growing urban tree canopies, daylighting and restoring urban streams and rivers, incentivizing and/or mandating eco-roofs, living walls and other biophilic urban design features, are all increasingly common tools used in the 15 cities that are part of the new global Biophilic Cities Network (BiophilicCities.org).

Cities like Edmonton, Canada have adopted an impressive ecological network plan to guide future growth, where there are now more than 27 wildlife passages to allow for faunal movement through the city. A new initiative there called "Breathe" extends this ecological network yet further to include rooftops and spaces between and around buildings, connecting the wildlife passages to places where people might interact with the wildlife [111].

It is important that cities grow and develop in ways that protect and grow nature, that put nature at the core of design and planning. Singapore, for instance, implements a Landscape Replacement Policy, which requires new buildings to at least replace 1-to-1 the nature lost at ground level with nature in the vertical realm. New high-rise buildings are in friendly competition to see which can design in the most vertical nature. The new Oasis building, recently completed, replaces ground level by some $900 \%$. A Skyrise Greenery division has been created within NParks (the National Parks Board) to support these efforts, and financial incentives, research and development, and an annual Skyrise Greenery award, also contribute to building this model of a compact, vertical urban greening. Singapore may be the most advanced example of a Biophilic City (Fig. 6), growing nature and stewarding over biodiversity in many ways, through many different planning and policy mechanisms. Singapore like many cities in the Network are profoundly redefining the role of nature. These cities are moving from the view of nature as something to be found only in certain places in the city--the park down the street, the community garden a block away, for instance--to a more nature-immersive view of cities. Singapore has even changed their official motto from "Singapore, A Garden City," to "Singapore, A City in a 


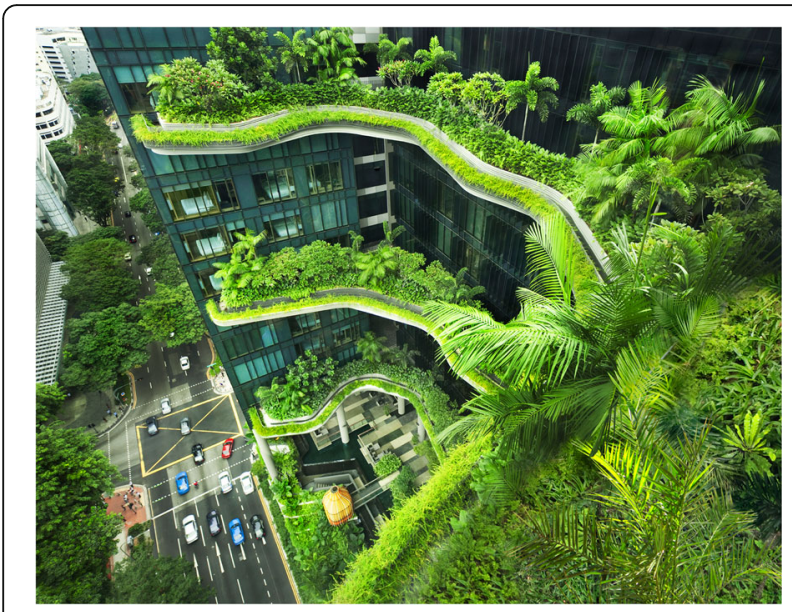

Fig. 6 An example of a green roof and façade from Singapore. Photo taken at the Royal Park Hotel. Note the abundant street trees along Pickering Street. Photo by Timothy Beatley

Garden”. It is a small and subtle change in words, but a profoundly different view of cities.

Creating cities where nature is integrated into the spaces where we live will require a variety of urban design and planning strategies. Cities must blend traditional conservation of remnant nature and natural systems, with more human-designed nature elements. Living walls and architecture can work together with urban forests and larger blocks of habitat for instance, to cool cities and to more effectively manage urban stormwater and flooding. Bird-friendly design guidelines that require bird-friendly glass and facade treatments (as in San Francisco) will work together with more traditional protection of bird habitat. Designing new pollinator pathways in cities, as seen in cities like Oslo, or ambitious targets for planting butterfly gardens, in cities like St Louis, suggest the ability to understand cities as biodiversity havens and positive contributors to global biodiversity conservation.

\section{Tensions}

There are significant obstacles to overcome on the way to this new vision of cities. While we have compelling models of how biophilic urbanism works in cities in the developed world, such as Singapore and San Francisco, how this model applies in less affluent settings (the Global South) is unclear. Where demands for addressing the needs of poverty are great and there is a large extent of informal housing, the kinds of biophilic design and planning that we see in cities like Singapore seem unrealistic. We would argue, however, that many of the biophilic tools, methods and interventions could work in cities in the Global South, and certainly the vision of immersive nature is just as compelling. Many elements of biophilic design can be designed and installed at the grassroots level, and in ways that address local needs (landscape elements that produce food, or capture potable water). And the incorporation of nature into informal settlements represents one of the potentially most powerful ways to improve health and well-being there.

Other kinds of obstacles arise in cities in the North. Good biophilic design runs the risk of creating unintended consequences in the form of higher housing prices and gentrification, as can be seen in the case of New York's High Line Park. We need further work to develop a suite of planning tools to minimize or moderate these negative impacts and to more effectively address the need for affordable housing. The preparation of an Equitable Development Plan in advance of building the new 11th Street Bridge Park in Washington, DC is one example of how biophilic design must take these potentially negative effects into account and to plan for their avoidance or mitigation.

Gaining sufficient political support for Biophilic Cities is another challenge, especially in an era where nature sometimes seems so expendable or of lesser importance. Forward-looking mayors, such as Bill Peduto in Pittsburgh or Anne Hildalgo of Paris, seem to understand that health and other benefits nature brings, as well as how this vision of natureful life can enhance the attractiveness of their cities. The helpful synergies and overlaps with climate change and resilience are one angle to build support. We believe that investments in urban trees, ecoroofs, green terraces, and other forms of biophilic design will reap great benefits both in reducing greenhouse gas emissions and in reducing the local impacts of climate change.

\section{Conclusions}

The urban century will profoundly alter many aspects of human society. In the past few centuries, humans have had a good deal of practice building cities, and have learned how proper urban planning and adequate infrastructure can ameliorate much of the urban health penalty. However, we have argued in this essay that the urban psychological penalty will be harder to overcome merely with more grey infrastructure. Inherent in what makes cities such a productive way to organize society, what one writer called our species greatest invention [4], is an increased pace of interaction and life that research has shown often leads to an urban psychological penalty. Growing scientific evidence shows that natural features in cities can counteract a significant fraction of this urban psychological penalty. Nature in cities allows us to have the benefits of urbanization, while also having livable cities in which we can thrive. It is for this reason that we refer to nature in cities as the "green soul of the concrete jungle", for nature can make cities more 
humane in the fundamental sense of according with the needs of human well-being and happiness.

The New Urban Agenda [10] points to the role of ecosystem services in risk reduction and natural resource management. These are important goals, but we believe natural features are needed also simply to make our urban home more humane. One central goal of the New Urban Agenda was to "produce just, safe, healthy, accessible, affordable, resilient, and sustainable cities." We believe the scientific evidence shows that access to and interaction with natural features is essential to meeting the New Urban Agenda's goal of health. If we do not build some nature into our cities, we risk creating an inhumane, grey world for ourselves. Without nature the urban century will fail.

Yet despite the growing body of evidence that interaction with nature is essential for mental health, humanity is mostly building cities without nature. Global datasets suggest that currently only $13 \%$ of urban dwellers may be living in close enough proximity with nature to experience its mental health benefit. We believe that another path could be followed, leading to a greener urban future. But the first step is for policymakers to recognize that access to and interaction with nature is a human right. We are far from the first to make this call (cf., [112-114]), but our review of the literature suggests that without a certain minimum amount of nature, we are increasing the urban psychological penalty for billions. We suggest that nature in cities must be seen not just as an amenity, but as a fundamental requirement for a functioning and healthy city.

\section{Acknowledgements}

The authors wish to thank their institutions for support during the research and writing of this paper. We thank also all the researchers whose work we cite- without their findings, this perspectives piece would not be possible.

\section{Funding}

The authors were supported during the writing of this manuscript by their respective institutions.

\section{Availability of data and materials}

The datasets used and/or analyzed during the current study are available from the corresponding author on reasonable request.

\section{Authors' contributions}

The authors jointly conceived and designed the manuscript. RIM lead the review and manuscript writing, while TB wrote sections on biophilia and TE wrote sections on nature-based solutions. All authors read and approved the final manuscript.

\section{Authors' information}

Dr. Robert McDonald is Lead Scientist for the Global Cities program at The Nature Conservancy. He researches the impact and dependences of cities on the natural world, and help direct the science behind much of the Conservancy's urban conservation work.

Address: Global Cities Program, The Nature Conservancy, 4245 Fairfax Drive, Arlington, VA 22203, USA.

Email: Rob_mcdonald@tnc.org

Timothy Beatley is the Teresa Heinz Professor of Sustainable Communities, in the Department of Urban and Environmental Planning, School of Architecture at the University of Virginia, where he has taught for the last 25 years. Much of Beatley's work focuses on the subject of sustainable communities, and creative strategies by which cities and towns can fundamentally reduce their ecological footprints, while at the same time becoming more livable and equitable places.

Address: Department of Urban \& Environmental Planning, Campbell Hall, University of Virginia, Charlottesville, VA 22904, USA.

Email: beatley@virginia.edu

Thomas Elmqvist is professor in Natural Resource Management at Stockholm Resilience Center. His research is focused on ecosystem services, land use change, urbanization, natural disturbances and components of resilience including the role of social institutions.

Address: Stockholm Resilience Centre, Stockholm University, Kräftriket 2B, SE10691, Sweden

Email: thomas.elmqvist@su.se

Ethics approval and consent to participate

Not applicable.

\section{Consent for publication}

Not applicable.

\section{Competing interests}

The authors declare they have no competing interests.

\section{Publisher's Note}

Springer Nature remains neutral with regard to jurisdictional claims in published maps and institutional affiliations.

\section{Author details}

${ }^{1}$ Global Cities Program, The Nature Conservancy, 4245 Fairfax Drive, Arlington, VA 22203, USA. ²Department of Urban and Environmental Planning, University of Virginia, Charlottesville, VA 22904, USA. ${ }^{3}$ Stockholm Resilience Center, Stockholm University, SE-10691 Stockholm, Sweden.

Received: 20 April 2018 Accepted: 6 September 2018

Published online: 25 October 2018

\section{References}

1. UNPD. World Urbanization Prospects: The 2014 Revision. New York: United Nations Population Division; 2014.

2. Seto K, Guneralp B, Hutyra L. Global forecasts of urban expansion to 2030 and direct impacts on biodiversity and carbon pools. Proc Natl Acad Sci. 2012:109:16083-8.

3. McDonald RI. Global urbanization: can ecologists identify a sustainable way forward? Front Ecol Environ. 2008:6:99-104.

4. Glaeser E. Triumph of the City: how our greatest invention makes us richer, smarter, greener, healthier, and happier. New York: Penquin Books; 2012

5. Knox PL, McCarthy L. Urbanization: an introduction to urban geography. 2005.

6. Elmqvist T, Fragkias M, Goodness J, Güneralp B, Marcotullio PJ, McDonald RI, Parnell S, Schewenius M, M. S, Seto K, Wilkinson C. Urbanization, biodiversity, and ecosystem services: challenges and opportunities, a global assessment. New York: Springer; 2013.

7. Ives CD, Lentini PE, Threlfall CG, Ikin K, Shanahan DF, Garrard GE, Bekessy SA, Fuller RA, Mumaw L, Rayner L. Cities are hotspots for threatened species. Glob Ecol Biogeogr. 2016;25:117-26.

8. McDonald RI, Forman RTT, Kareiva P, Neugarten R, Salzer D, Fisher J. Urban effects, distance, and protected areas in an urbanizing world. Landsc Urban Plan. 2009;93:63-75.

9. McDonald Rl, Guneralp B, Huang C-W, Seto K, You M. Conservation priorities to protect vertebrate endemics from global urban expansion. Biol Conserv. 2018;224:290-9.

10. UN Habitat. Habitat III: New Urban Agenda. Quito. Online at: http://habitat3. org/wp-content/uploads/NUA-English.pdf: UN Habitat; 2016.

11. Montgomery M, Stren R, Cohen B, Reed HE. Cities transformed: demographic change and its implications in the developing world. Washington, DC: National Academies Press; 2003.

12. Puga D. The magnitude and causes of agglomeration economies. J Reg Sci. 2010:50:203-19.

13. Bettencourt L, Lobo J, Helbing D, Kuhnert C, West G. Growth, innovation, scaling, and the pace of life in cities. Proc Natl Acad Sci. 2007;104:7301-6. 
14. Bettencourt LM. The origins of scaling in cities. science. 2013;340:1438-41.

15. Bettencourt LM, Lobo J, Strumsky D, West GB. Urban scaling and its deviations: revealing the structure of wealth, innovation and crime across cities. PLoS One. 2010;5:e13541.

16. Aristotle, Politics. "trans. Ernest Barker." New York: Oxford University Press 3, no. 16 (1958): 296

17. Fujita M, Thisse J-F. Economics of agglomeration: cities, industrial location, and regional growth. Cambridge, UK: Cambridge University Press; 2002.

18. Duranton G, Puga D. Micro-foundations of urban agglomeration economies. Handb Reg urban Econ. 2004;4:2063-117.

19. Andersson F, Burgess S, Lane J. Cities, matching and the productivity gains of agglomeration. J Urban Econ. 2007;61:112-28.

20. Duranton G. From cities to productivity and growth in developing countries. Can J Econ/Revue canadienne économique. 2008;41:689-736.

21. Venables AJ. Productivity in cities: self-selection and sorting. J Econ Geogr. 2010;11:241-51.

22. Wheeler $\mathrm{CH}$. Search, sorting, and urban agglomeration. J Labor Econ. 2001; 19:879-99.

23. Wheeler $\mathrm{CH}$. Cities and the growth of wages among young workers: evidence from the NLSY. J Urban Econ. 2006;60:162-84.

24. Lee N, Rodríguez-Pose A. Creativity, cities, and innovation. Environ Plan A. 2014;46:1139-59.

25. Glaeser EL, Resseger MG. The complementarity between cities and skills. J Reg Sci. 2010;50:221-44.

26. Von Hippel E. "Sticky information" and the locus of problem solving: implications for innovation. Manag Sci. 1994;40:429-39.

27. Fallick B, Fleischman CA, Rebitzer JB. Job-hopping in Silicon Valley: some evidence concerning the microfoundations of a high-technology cluster. Rev Econ Stat. 2006;88:472-81.

28. Glaeser EL, Kolko J, Saiz A. Consumer city. J Econ Geogr. 2001;1:27-50.

29. Shapiro JM. Smart cities: quality of life, productivity, and the growth effects of human capital. Rev Econ Stat. 2006;88:324-35.

30. McDonald Rl. Conservation for cities: how to plan \& build natural infrastructure. Washington, DC: Island Press; 2015.

31. Jones GA, Corbridge S. The continuing debate about urban bias: the thesis, its critics, its influence and its implications for poverty-reduction strategies. Prog Dev Stud. 2010;10:1-18.

32. McDonald RI, Marcotullio P. Global effects of urbanization on ecosystem services. In: Niemelä J, editor. Handbook of urban ecology. Oxford, UK: Oxford University Press; 2011.

33. McGranahan G, Satterthwaite D. The environmental dimensions of sustainable development for cities. Geography. 2002;87:213-26.

34. Kearns G. The urban penalty and the population history of England. 1988.

35. Vlahov D, Galea S. Urbanization, urbanicity, and health. J Urban Health. 2002;79:S1-S12.

36. McGranahan G. Urban transitions and the spatial displacement of environmental burdens. In: Marcotullio P, McGranahan G, editors. Scaling urban environmental challenges: from local to global and Back. London: Earthscan; 2007. p. 18-44.

37. Marcotullio P. Urban water-related environmental transitions in Southeast Asia. Sustain Sci. 2007. https://doi.org/10.1007/s11625-006-0019-0.

38. Melosi MV. The sanitary city. Pittsburg, PA: University of Pittsburg Press; 2008.

39. WHO UNICEF. Progress on drinking water, sanitation, and hygiene. Geneva: World Health Organization; 2017

40. Bell ML, Davis DL, Fletcher T. A retrospective assessment of mortality from the London smog episode of 1952: the role of influenza and pollution. Environ Health Perspect. 2004;112:6.

41. Fouquet R. Long run trends in energy-related external costs. Ecol Econ. 2011;70:2380-9.

42. EPA. Air Quality- National Summary. Online at https:/www.epa.gov/air-trends/ air-quality-national-summary: Environmental Protection Agency.; 2016.

43. Lim SS, Vos T, Flaxman AD, Danaei G, Shibuya K, Adair-Rohani H, AlMazroa MA, Amann M, Anderson HR, Andrews KG, et al. A comparative risk assessment of burden of disease and injury attributable to 67 risk factors and risk factor clusters in 21 regions, 1990\&\#x2013;2010: a systematic analysis for the Global Burden of Disease Study 2010. Lancet. 2013;380: 2224-60.

44. Leon DA. Cities, urbanization and health. Oxford: Oxford University Press; 2008.

45. Vlahov D, Galea S, Freudenberg N. The urban health "advantage". J Urban Health. 2005;82:1-4.
46. UN-HABITAT. World Cities Report. Online at http://gsdrc.org/documentlibrary/world-cities-report-2016/: United Nations Human Settlements Programme (UN-Habitat); 2016.

47. Allender S, Foster C, Hutchinson L, Arambepola C. Quantification of urbanization in relation to chronic diseases in developing countries: a systematic review. J Urban Health. 2008;85:938-51.

48. WHO. Obesity and overweight factsheet. Available online at http://www. who.int/news-room/fact-sheets/detail/obesity-and-overweight: World Health Organization; 2017.

49. Swinburn BA, Sacks G, Hall KD, McPherson K, Finegood DT, Moodie ML, Gortmaker SL. The global obesity pandemic: shaped by global drivers and local environments. Lancet. 2011;378:804-14.

50. Ewing R, Schmid T, Killingsworth R, Zlot A, Raudenbush S. Relationship between urban sprawl and physical activity, obesity, and morbidity. Am J Health Promot. 2003:18:47-57.

51. Gruebner O, Rapp MA, Adli M, Kluge U, Galea S, Heinz A. Cities and mental health. Dtsch Arztebl Int. 2017:114:121.

52. Lederbogen F, Kirsch P, Haddad L, Streit F, Tost H, Schuch P, Wust S, Pruessner JC, Rietschel M, Deuschle M, Meyer-Lindenberg A. City living and urban upbringing affect neural social stress processing in humans. Nature. 2011:474:498-501.

53. Sundquist K, Frank G, Sundquist J. Urbanisation and incidence of psychosis and depression. Br J Psychiatry. 2004;184:293-8.

54. Mortensen PB, Pedersen CB, Westergaard T, Wohlfahrt J, Ewald H, Mors O, Andersen PK, Melbye M. Effects of family history and place and season of birth on the risk of schizophrenia. N Engl J Med. 1999;340:603-8.

55. Pedersen CB, Mortensen PB. Evidence of a dose-response relationship between urbanicity during upbringing and schizophrenia risk. Arch Gen Psychiatry. 2001;58:1039-46.

56. Newbury J, Arseneault L, Caspi A, Moffitt TE, Odgers CL, Fisher HL. Why are children in urban neighborhoods at increased risk for psychotic symptoms? Findings from a UK longitudinal cohort study. Schizophr Bull. 2016:42:1372-83.

57. Paykel E, Abbott R, Jenkins R, Brugha T, Meltzer H. Urban-rural mental health differences in Great Britain: findings from the National Morbidity Survey. Psychol Med. 2000;30:269-80.

58. Chan KY, Ff Z, Meng S, Demaio AR, Reed C, Theodoratou E, Campbell H, Wang W, Rudan I. Urbanization and the prevalence of schizophrenia in China between 1990 and 2010. World Psychiatry. 2015;14:251-2.

59. Andrade LH, Wang Y-P, Andreoni S, Silveira CM, Alexandrino-Silva C, Siu ER, Nishimura R, Anthony JC, Gattaz WF, Kessler RC. Mental disorders in megacities: findings from the Sao Paulo megacity mental health survey, Brazil. PLoS One. 2012;7:e31879.

60. Pillay A, Naidoo P, Lockhat M. Psychopathology in urban and rural/periurban children seeking mental health care. S Afr J Psychol. 1999;29:178-83.

61. Cuffe SP, Moore CG, McKeown RE. Prevalence and correlates of ADHD symptoms in the national health interview survey. J Atten Disord. 2005;9: 392-401.

62. Freeman H. Schizophrenia and city residence. Br J Psychiatry. 1994(23):39-50.

63. Lewis G, David A, Andréassson S, Allebeck P. Schizophrenia and city life. Lancet. 1992;340:137-40.

64. Stanley D. What do we know about social cohesion: the research perspective of the federal government's social cohesion research network Can J Sociol/Cahiers canadiens de sociologie. 2003;28(1):5.

65. Wirth L. Urbanism as a way of life. Am J Sociol. 1938;44:1-24.

66. Saunders P. Social theory and the urban question. London: Routledge; 2003.

67. Evans GW. The built environment and mental health. J Urban Health. 2003; 80:536-55.

68. Moudon AV. Real noise from the urban environment: how ambient community noise affects health and what can be done about it. Am J Prev Med. 2009;37:167-71.

69. Hammersen F, Niemann H, Hoebel J. Environmental noise annoyance and mental health in adults: findings from the cross-sectional German health update (GEDA) study 2012. Int J Environ Res Public Health. 2016; 13:954.

70. Chepesiuk R. Missing the dark: health effects of light pollution. Environ Health Perspect. 2009;117:A20.

71. Epstein YM. Crowding stress and human behavior. J Soc Issues. 1981;37:126-44

72. Evans GW. Behavioral and physiological consequences of crowding in humans. J Appl Soc Psychol. 1979;9:27-46.

73. Kabisch N, Frantzeskaki N, Pauleit P, Naumann S, Davis M, Artmann M, Haase $D$ et al. Nature-based solutions to climate change mitigation and 
adaptation in urban areas: perspectives on indicators, knowledge gaps, barriers, and opportunities for action. Ecol Soc. 2016;21.

74. Directorate-General E. Towards an EU Research and Innovation Policy Agenda for Nature-Based Solutions \& Re-Naturing Cities. Brussels. Available online at: https://ec.europa.eu/research/environment/index.cfm?pg=nbs: EU Directorate-General for Research and Innovation; 2015.

75. MEA. Ecosystems and Human Well-Being: A framework for assessment. Washington, D.C.: Island Press; 2003.

76. Beck M, Gilmer B, Ferdaña Z, Raber GT, Shepard C, Meliane I, Stone J, Whelchel A, Hoover M, Newkirk S. Increasing the resilience of human and natural communities to coastal hazards: supporting decisions in New York and Connecticut. In: Renaud F, Sudmeier-Rieux K, Estrella M, editors. The role of ecosystems in disaster risk reduction. Tokyo: United Nations University Press; 2013.

77. Kousky C, Walls M. Floodplain conservation as a flood mitigation strategy: examining costs and benefits. Washington, DC: Resources for the Future; 2013.

78. Opperman J, Galloway G, Fargione J, Mount J, Richter B, Secchi S. Sustainable floodplains through large-scale reconnection to rivers. Science. 2009;326:1487-8

79. NRDC. Financing stormwater retrofits in Philadelphia and beyond. New York: National Resources Defense Council; 2012.

80. McDonald Rl, Shemie D. Urban water blueprint: Mapping conservation solutions to the global water challenge. Washington, DC. Available online at: nature.org/waterblueprint: The Nature Conservancy. ; 2014.

81. McDonald Rl, Kroeger T, Boucher T, Wang L, Salem R. Planting healthy air: a global analysis of the role of urban trees in addressing particulate matter pollution and extreme heat. Arlington, VA: The Nature Conservancy; 2016.

82. Lindgren E, Elmqvist T. Ecosystem services and human health. In: vd B, editor Nature and health. Edited by bird. Oxford: Oxford University Press; 2017.

83. Hartig T, Mitchell R, De Vries S, Frumkin H. Nature and health. Annu Rev Public Health. 2014:35:207-28.

84. Hartig T, Kahn PH. Living in cities, naturally. Science. 2016;352:938-40.

85. Frumkin H, Bratman GN, Breslow SJ, Cochran B, Kahn PH Jr, Lawler JJ, Levin PS, Tandon PS, Varanasi U, Wolf KL. Nature contact and human health: a research agenda. Environ Health Perspect. 2017;125:075001.

86. Wolch J, Jerrett M, Reynolds K, McConnell R, Chang R, Dahmann N, Brady K, Gilliand F, Su J, Berhane K. Childhood obesity and proximity to urban parks and recreational resources: a longitudinal cohort study. Health Place. 2011; 17:207-14.

87. Bratman GN, Hamilton J, Daily G. The impacts of nature experience on human cognitive function and mental health. Ann N Y Acad Sci. 2012;1249: 118-36.

88. Van den Berg M, Wendel-Vos W, Van Poppel M, Kemper H, Van Mechelen W, Maas J. Health benefits of green spaces in the living environment: a systematic review of epidemiological studies. Urban For Urban Green. 2015; 14:806-16.

89. Maas J, Van Dillen SME, Verheik RA, Groenewegen PP. Social contacts as a possible mechanism behind the relation between green space and health. Health Place. 2009;15:586-95.

90. de Vries S, van Dillen SM, Groenewegen PP, Spreeuwenberg P. Streetscape greenery and health: stress, social cohesion and physical activity as mediators. Soc Sci Med. 2013:94:26-33.

91. Kuo FE, Sullivan WC, Coley RL, Brunson L. Fertile ground for community: Inner-City neighborhood common spaces. Am J Community Psychol. 1998; 26:823-51.

92. Stigsdotter UK, Ekholm O, Schipperijn J, Toftager M, Kamper-Jørgensen F, Randrup TB. Health promoting outdoor environments-associations between green space, and health, health-related quality of life and stress based on a Danish national representative survey. Scand J Soc Med. 2010;38:411-7.

93. Thompson CW, Roe J, Aspinall P, Mitchell R, Clow A, Miller D. More green space is linked to less stress in deprived communities: evidence from salivary cortisol patterns. Landsc Urban Plan. 2012;105:221-9.

94. Bjørnstad S, Patil GG, Raanaas RK. Nature contact and organizational support during office working hours: benefits relating to stress reduction, subjective health complaints, and sick leave. Work. 2016:53:9-20.

95. Ulrich RS, Simons RF, Losito BD, Fiorito E, Miles MA, Zelson M. Stress recovery during exposure to natural and urban environments. J Environ Psychol. 1991;11:201-30.

96. Kaplan R, Kaplan S. The experience of nature: a psychological perspective. New York: Cambridge University Press; 1989.
97. Alcock I, White MP, Wheeler BW, Fleming LE, Depledge MH. Longitudinal effects on mental health of moving to greener and less green urban areas. Environ Sci Technol. 2014;48:1247-55.

98. White MP, Alcock I, Wheeler BW, Depledge MH. Would you be happier living in a greener urban area? A fixed-effects analysis of panel data. Psycho Sci. 2013;24:920-8.

99. Astell-Burt T, Feng X, Kolt GS. Mental health benefits of neighbourhood green space are stronger among physically active adults in middle-to-older age: evidence from 260,061 Australians. Prev Med. 2013;57:601-6.

100. Lovasi GS, Quinn JW, Neckerman KM, Perzanowski MS, Rundle A. Children living in areas with more street trees have lower prevalence of asthma. J Epidemiol Community Health. 2008;62:647-9.

101. Shanahan DF, Bush R, Gaston KJ, Lin BB, Dean J, Barber E, Fuller RA. Health benefits from nature experiences depend on dose. Sci Rep. 2016;6:28551.

102. Cox DT, Shanahan DF, Hudson HL, Plummer KE, Siriwardena GM, Fuller RA Anderson K, Hancock S, Gaston KJ. Doses of neighborhood nature: the benefits for mental health of living with nature. BioScience. 2017;67:147-55.

103. Landry SM, Chakraborty J. Street trees and equity: evaluating the spatial distribution of an urban amenity. Environ Plan A. 2009;41:2651-70.

104. Boone CG, Buckley GL, Grove JM, Sister C. Parks and people: an environmental justice inquiry in Baltimore, Maryland. Ann Assoc Am Geogr. 2009:99:767-87.

105. Beatley T. Biophilic cities: integrating nature into Urban Design and planning. Washington, DC: Island Press; 2010.

106. Kellert SR, Heerwagen J, Mador M. Biophilic design: the theory, science and practice of bringing buildings to life. Hoboken: Wiley; 2011.

107. Kellert S, Wilson EO. The biophilia hypothesis. Washington, DC: Island Press; 1995.

108. Elley CR, Kerse N, Arroll B, Robinson E. Effectiveness of counselling patients on physical activity in general practice: cluster randomised controlled trial. Bmj. 2003;326:793.

109. Hamlin M, Yule E, Elliot C, Stoner L, Kathiravel Y. Long-term effectiveness of the New Zealand green prescription primary health care exercise initiative. Public Health. 2016;140:102-8.

110. Leung W, Ashton T, Kolt GS, Schofield GM, Garrett N, Kerse N, Patel A. Costeffectiveness of pedometer-based versus time-based green prescriptions: the healthy steps study. Aust J Prim Health. 2012;18:204-11.

111. Edmunton Co. Breathe: The future of Edmonton's Green Network. Online at https://www.edmonton.ca/city_government/initiatives_innovation/breathe. aspx: City of Edmunton; 2017.

112. Soga M, Gaston KJ. Extinction of experience: the loss of human-nature interactions. Front Ecol Environ. 2016:14:94-101.

113. IUCN. The Child's Right to Connect with Nature and to a Healthy Environment. Online at https://portals.iucn.org/docs/2012congress/motions/ en/M-132-2012-EN.pdf: IUCN; 2012.

114. Louv R. Last child in the woods: saving our children from nature-deficit disorder. Chapel Hill: Algonquin Books; 2008

115. MEA. Millennium Ecosystem Assessment Synthesis Report. Washington, D.C. Island Press; 2005

\section{Ready to submit your research? Choose BMC and benefit from:}

- fast, convenient online submission

- thorough peer review by experienced researchers in your field

- rapid publication on acceptance

- support for research data, including large and complex data types

- gold Open Access which fosters wider collaboration and increased citations

- maximum visibility for your research: over $100 \mathrm{M}$ website views per year

At BMC, research is always in progress.

Learn more biomedcentral.com/submissions 